\title{
The Design And Implementation Of An Enlivened IFRS Course
}

Mark Holtzblatt, Roosevelt University, USA

Norbert Tschakert, University of the Virgin Islands, Virgin Islands

\begin{abstract}
In the Spring/2009 semester, with the financial support of a PricewaterhouseCoopers IFRS Ready Grant, a new course was developed that focused on International Financial Reporting Standards (IFRS). The course design goal was to choose the optimal combination of pedagogical tools and topics to create an effective, engaging and stimulating course plan. The course incorporates the online e-IFRS created by the International Accounting Standards Board (IASB), e-Learning IFRS Modules from the global accounting firm of Deloitte and IFRS Expert online videos and webcasts from corporate and various institutional and academic institutions. The pedagogical techniques described herein are also applicable to introductory accounting and finance classes, intermediate and advanced accounting classes and the international accounting and theory classes.
\end{abstract}

Keywords: IFRS, Pedagogy, Online Videos, E-Learning, E-IFRS, Core Competencies

\section{INTRODUCTION}

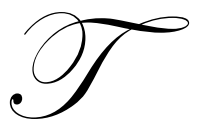

his teaching innovation originated in September of 2008 during the early weeks of the Fall semester. In the International Accounting class, two IFRS videos were shown to the students. The first was an eight-minute IFRS.com video entitled "IFRS: Adopting Global Standards" provided by the American Institute of Certified Public Accountants (AICPA). The second was a seven-minute IFRS video from PwC.tv, the PricewaterhouseCoopers (PwC) student-oriented website. Both of these IFRS videos were high quality productions with numerous experts offering insights into IFRS. After screening these two IFRS videos, a very favorable student reaction was observed in terms of both increased attentiveness and the quality of discussions generated.

With such a positive classroom experience, the decision was made to seek out additional IFRS videos by conducting various internet searches. Ultimately, a comprehensive body of IFRS multimedia presentations was accumulated. However, the collection was extremely disorganized, so order was instilled by categorizing and classifying them. Once an organized structure was created, the next step was to think of strategies to incorporate these IFRS videos and webcasts into various courses throughout the accounting curriculum.

About the same time as the IFRS video and webcast searches were underway, PwC promoted their IFRS Ready Grant Program. The PwC grant program was designed to encourage U.S. faculty and universities to integrate IFRS into their curriculum. A PwC IFRS Ready grant proposal was submitted that described the creation of an IFRS course optimized by a combination of e-IFRS, online interactive IFRS training material and a combination of expert IFRS videos and webcasts. In mid-December of 2008, notification was received of being a recipient of the PwC IFRS Ready Grant.

The IFRS course was subsequently designed during the Spring/2009 semester and implemented for the first time during the 12-week Summer term of 2009 at both the graduate and undergraduate levels. This class has subsequently been offered in the Fall/2009 and Spring/2010 semesters. 
The pedagogical resources of the IFRS course include:

1. e-IFRS by the IASB via a student membership for $\$ 20$ in the International Association for Accounting Education and Research (IAAER).

2. IFRS e-Learning by Deloitte which currently contains 39 IFRS modules. This is a $\$ 4$ million professional online interactive training program available at zero cost to the students.

3. IFRS videos and webcasts which have been referred to as "IFRS Cyber-Guest Lecturers" with special emphasis on the use of the PwC IFRS Video Learning Center (VLC). The PwC IFRS VLC videos are beneficial for in-class viewing due to their reasonable duration and the use of synchronized power points.

The e-IFRS by the IASB was chosen for the IFRS course because it gives students the opportunity to experience researching the actual standards via the same online service they will likely use in the future during their professional careers. The e-IFRS may be referenced when working on the Deloitte e-Learning IFRS modules or other assigned questions, exercises and cases.

The IFRS e-Learning by Deloitte was selected after evaluating several online IFRS certificate programs and professional training programs. The IFRS Certificate programs offered by the Association of Chartered and Certified Accountants (ACCA) and the Institute of Chartered Accountants of England and Wales (ICAEW) offered a desirable goal (i.e., certificate), but were relatively costly at $\$ 300$ to $\$ 600$ per student. In addition, these certificate programs are also targeted for finance professionals and were found less accounting-intensive than desired for the IFRS courses, which are primarily for accounting majors. The PwC P2P IFRS modules were also considered, but PwC favors to provide these modules to an audience with a more experienced background than a typical student. Thus, the Deloitte modules were chosen. These modules have the valuable feature of placing students into "scenarios" which realistically imitate job situations. These scenarios involve deadlines to be met, incoming emails, phone calls, faxes, face-to-face client meetings, continuous research assignments and continual online testing of the newly acquired knowledge. The Deloitte modules take learning to a new interactive technological level and experience rather than just having students read a printed book or articles. Also, the students have free access to the entire body of IFRS training modules.

The IFRS videos and webcasts enliven the class by introducing the students to IFRS experts from public accounting, industry, standard setting bodies, government regulators and a variety of professional accounting societies from around the world. For example, the 2009 summer IFRS graduate students heard and saw Sir David Tweedie, Chairman of the IASB, 10 to 15 partners and managers from PWC, KPMG and EY, former SEC Chairman Christopher Cox, Aaron Anderson, the Director of IFRS Policy for IBM and Dr. Kamal Gupta, the Technical Director of the Institute of Chartered Accountants of India. As "virtual" guest speakers, these classroom "visits" involved absolutely no cost to the university and the students were able to review the videos and webcasts multiple times on their own, if desired, via archived links.

\section{AN IN-DEPTH LOOK INTO THE DEVELOPMENT OF OUR IFRS COURSE}

\section{Course Learning Objectives}

To begin the course design, a list of objectives of the new class were delineated so the chosen pedagogical tools would have a benchmark to be compared to. It is obviously impossible to cover all the IFRS pronouncements in depth in a single semester course. Thus, an overriding goal in the course development was to equip the students with the knowledge of the available IFRS tools and resources so they would be able to learn and research the global standards on their own well beyond the course conclusion. To adopt the famous analogy, we set out to teach the students "how to fish" rather than to simply "give them the fish". This will be a valuable skill set when the student later works in an accounting firm and has to research such topics on his own. Table 1 is a list of established learning objectives. 
Table 1: Learning Objectives for the Newly Designed Enlivened IFRS Course

\begin{tabular}{|c|l|}
\hline No. & IFRS Course Learning Objective Description \\
\hline 1 & The History and Structure of the International Accounting Standards Board (IASB) \\
\hline 2 & The Standard-Setting Process of the IASB and the Conceptual Framework \\
\hline 3 & The Significant Differences Between IFRS and U.S. GAAP \\
\hline 4 & Adoption and Convergence Status of IFRS in the U.S. and throughout the World \\
\hline 5 & The Arguments in Favor of and the Arguments Opposing IFRS Adoption in the U.S. \\
\hline 6 & Methods of Recognition and Measurement under IFRS \\
\hline 8 & Preparation and Presentation of Financial Statements under IFRS \\
\hline 9 & Methods of Recording Transactions under IFRS \\
\hline 10 & Fesearching the e-IFRS Resource Database created by the IASB \\
\hline
\end{tabular}

These objectives give the students the proper theoretical and conceptual framework, combined with sufficient coverage of significant IFRS rules and procedures.

\section{E-IFRS BY THE INTERNATIONAL ACCOUNTING STANDARDS BOARD (IASB)}

In order to provide the students with the research skills necessary for working with the IFRS in their future careers we wanted to provide them with the training and access to the actual IFRS standards. We also wanted to use an internet based resource for accessing the standards as these databases are constantly updated and most likely equivalent to those that students will encounter on the job. At the time of the initial course design and development during the Spring and Summer of 2009, the only affordable online access to the IFRS standards was via a student membership in the IAAER. The IAAER is a global not-for-profit organization with the mission to promote excellence in accounting education and research on a worldwide basis and to maximize the contribution of accounting academics to the development and maintenance of high quality, globally recognized standards of accounting practice. The IAAER was founded in 1984 and its homepage is www.iaaer.org.

Faculty and student members of the IAAER enjoy full, unlimited access to all e-IFRSs. This includes the most up-to-date electronic PDF versions of all IFRS, International Accounting Standards (IASs), Interpretations (IFRICs/SICs) and IASB-issued supporting documents which includes application guidance, illustrative examples, implementation guidance, basis for conclusions and appendices. Normally $£ 200$ for a one year subscription, the IAAER has collaborated with the IASB and KPMG to offer this valuable resource at a discounted rate of US\$25 for faculty for one full year. Membership for students and current accounting classes is also available at a rate of US\$20 for students. Student memberships to the IAAER including full access to the e-IFRS are available at https://members.iaaer.org/Join/RegistrationStudent.aspx

Since the initial creation of our IFRS course, an alternative has arisen to the paid subscription e-IFRS access offered by the membership in the IAAER. The IASC Foundation in the UK, the oversight body of the IASB, now provides access free of charge to the current year's consolidated unaccompanied IFRS in English as issued by the IASB and published in the Bound Volume. Access to the accompanying documents, illustrative examples, implementation guidance and basis for conclusions is available via the IASB subscription-based services or by purchasing print versions of IFRS via the IASB store. Thus for those students and/or faculty that only require the unaccompanied IFRS, this text is now available for free and accessible at http://www.iasb.org/IFRSs/IFRS.htm. If a professor or student desires to access the full version of IFRS, the low-cost IAAER membership with e-IFRS access is the best option. Table 2 provides an overview of currently available standards through the IASB website. 
Table 2: The Unaccompanied IFRSs as Issued at 1 January 2010 in English

\begin{tabular}{|c|c|c|c|c|c|}
\hline & & & & & \\
\hline Preface & IFRS 1 & IAS 1 & IAS 27 & IFRIC 1 & SIC 7 \\
\hline \multirow[t]{15}{*}{ Framework } & IFRS 2 & IAS 2 & IAS 28 & IFRIC 2 & SIC 10 \\
\hline & IFRS 3 & IAS 7 & IAS 29 & IFRIC 4 & SIC 12 \\
\hline & IFRS 4 & IAS 8 & IAS 31 & IFRIC 5 & SIC 13 \\
\hline & IFRS 5 & IAS 10 & IAS 32 & IFRIC 6 & SIC 15 \\
\hline & IFRS 6 & IAS 11 & IAS 33 & IFRIC 7 & SIC 21 \\
\hline & IFRS 7 & IAS 12 & IAS 34 & IFRIC 8 & SIC 25 \\
\hline & IFRS 8 & IAS 16 & IAS 36 & IFRIC 9 & SIC 27 \\
\hline & IFRS 9 & IAS 17 & IAS 37 & IFRIC 10 & SIC 29 \\
\hline & & IAS 18 & IAS 38 & IFRIC 11 & SIC 31 \\
\hline & & IAS 19 & IAS 39 & IFRIC 12 & SIC 32 \\
\hline & & IAS 20 & IAS 40 & IFRIC 13 & \\
\hline & & IAS 21 & IAS 41 & IFRIC 14 & \\
\hline & & IAS 23 & & IFRIC 15 & \\
\hline & & IAS 24 & & IFRIC 16 & \\
\hline & & IAS 26 & & IFRIC 17 & \\
\hline
\end{tabular}

\section{IFRS E-LEARNING BY DELOITTE}

In 2004, Deloitte launched a comprehensive set of e-Learning modules on IFRS. Developed with an investment of around US $\$ 4,000,000$, the IFRS e-Learning program was initially intended to help prepare Deloitte partners and staff for the adoption of IFRS in Europe and throughout the world. After releasing the program internally, Deloitte decided to make it available to the public at large without charge.

A total of 39 modules have been released. The modules are primarily interactive cases from the viewpoint of an auditor who encounters application of an individual IFRS. The cases are real business scenarios to demonstrate the application of the standards. Each module contains "Coach Me" sections to explain the principles and theory of the relevant IFRS. Examples are included that show aspects of the standards in action. At the conclusion of each module, students can obtain a printable certificate upon passing the multiple choice assessment test with a grade of $70 \%$ or above. It normally takes students one to two hours to complete a module. Students should have the relevant IFRS available as a reference.

The e-IFRS Learning by Deloitte has become very popular. To date, over 3,000,000 Deloitte IFRS elearning modules have been downloaded from Deloitte's website www.iasplus.com. Many of the modules downloaded have multiple users because organizations are permitted to install them on their own servers for the internal use of their employees or students. Many major corporations have chosen to use Deloitte IFRS e-learning as their primary tool for educating their staff on IFRS. In addition, the modules are widely used by Deloitte staff throughout the global organization, who access them via an intranet.

The Deloitte IFRS e-Learning modules are obtainable by clicking on the light-bulb icon on the home page of Deloitte's website www.iasplus.com or navigating directly to www.deloitteifrslearning.com. There is no charge, but you are asked to register and provide a few pieces of information. Each module is a $2 \mathrm{mb}$ to $6 \mathrm{mb}$ download of a ZIP file. You can extract the compressed files to a directory on your hard disk or server. Full installation instructions are provided on the website. The modules are kept up to date as the IASB publishes new and amended pronouncements. Table 3 lists the currently available Deloitte IFRS e-Learning modules. 
Table 3: Deloitte IFRS e-Learning Modules as of April 2010

\begin{tabular}{|c|c|c|}
\hline Standard & Title of e-Learning Module & Version \\
\hline & Using IFRS e-Learning & $\mathrm{v} 8$ \\
\hline & Framework for the Preparation and Presentation of Financial Statements & v9 \\
\hline IAS 1 & Presentation of Financial Statements & v9 \\
\hline IAS 2 & Inventories & $\mathrm{v} 9$ \\
\hline IAS 7 & Cash Flow Statements & v9 \\
\hline IAS 8 & Accounting Policies, Changes in Accounting Estimates, and Errors & v9 \\
\hline IAS 10 & Events After the Reporting Period & v9 \\
\hline IAS 11 & Construction Contracts & $\mathrm{v} 9$ \\
\hline IAS 12 & Income Taxes & v9 \\
\hline IAS 14 & Segment Reporting & v9 \\
\hline IAS 16 & Property, Plant and Equipment & $\mathrm{v} 9$ \\
\hline IAS 17 & Leases & $\mathrm{v} 9$ \\
\hline IAS 18 & Revenue & $\mathrm{v} 9$ \\
\hline IAS 19 & Employee Benefits & v9 \\
\hline IAS 21 & The Effects of Changes in Foreign Exchange Rates & $\mathrm{v} 9$ \\
\hline IAS 23 & Borrowing Costs & v9 \\
\hline IAS 24 & Related Party Disclosures & $\mathrm{v} 9$ \\
\hline IAS 27 & Consolidated and Separate Financial Statements (covers revision to IAS 27 as at 12/2003) & $\mathrm{v} 8$ \\
\hline IAS 27 & Consolidated and Separate Financial Statements (covers revision to IAS 27 as at 5/2008) & v9 \\
\hline IAS 28 & Accounting for Investments in Associates (covers revision to IAS 28 as at 12/2003) & $\mathrm{v} 8$ \\
\hline IAS 28 & Accounting for Investments in Associates (covers revision to IAS 28 as at 5/2008) & v9 \\
\hline IAS 29 & Financial Reporting in Hyperinflationary Economies & v9 \\
\hline IAS 31 & Financial Reporting of Interests in Joint Ventures (covers revision to IAS 31 as at 12/2003) & $\mathrm{v} 8$ \\
\hline IAS 31 & Financial Reporting of Interests in Joint Ventures (covers revision to IAS 31 as at 5/2008) & v9 \\
\hline IAS 32/39 & Accounting for Financial Instruments & v9 \\
\hline IAS $32 / 39$ & Hedge Accounting & $\mathrm{v} 9$ \\
\hline IAS 32/39 & Derecognition of Financial Instruments & $\mathrm{v} 9$ \\
\hline IAS 33 & Earnings Per Share & v9 \\
\hline IAS 34 & Interim Financial Statements & $\mathrm{v} 9$ \\
\hline IAS 36 & Impairment of Assets & v9 \\
\hline IAS 37 & Provisions, Contingent Liabilities and Contingent Assets & v9 \\
\hline IAS 38 & Intangible Assets & $\mathrm{v} 9$ \\
\hline IAS 40 & Investment Property & $\mathrm{v} 9$ \\
\hline IAS 41 & Agriculture & v9 \\
\hline IFRS 1 & First-time Adoption of International Financial Reporting Standards & v9 \\
\hline IFRS 2 & Share-based Payment & v9 \\
\hline IFRS 3 & Business Combinations (covers revision to IFRS 3 as at December 2003) & $\mathrm{v} 8$ \\
\hline IFRS 3 & Business Combinations (covers revision to IFRS 3 as at May 2008) & v9 \\
\hline IFRS 5 & Non-current Assets Held for Sale and Discontinued Operations & v9 \\
\hline IFRS 8 & Operating Segments & v9 \\
\hline IFRIC 12 & Service Concession Arrangements & v9 \\
\hline
\end{tabular}

\section{IFRS WEBCASTS AND ONLINE VIDEOS}

The third component of online pedagogical tools that is incorporated into the newly designed IFRS course are the IFRS Expert Online Videos and Webcasts. The number of online videos and webcasts dealing with the international accounting standards has accelerated sharply since the publication of the SEC's "Roadmap to IFRS" in Fall 2008. When viewed as a group, the entire collection of IFRS webcasts is impressive.

The creators and hosts of the majority of IFRS webcast presentations include the major global accounting firms, the AICPA, the Canadian Institute of Chartered Accountants (CICA), the Securities and Exchange Commission (SEC) and educational institutions. The accounting firms' efforts have been led by the "Big 4" firms including Deloitte, EY, KPMG and PwC. 
Deloitte provides a link on their main IFRS homepage entitled "Dbriefs: IFRS Webcasts". There are currently fourteen different IFRS webcasts available, ranging from discussions of general IFRS differences to specific webcasts focusing upon selected industries (i.e., Oil \& Gas, Real Estate, and Insurance).

EY has a link on their global IFRS homepage for all current and archived IFRS webcasts. The webcasts range from audio/powerpoint to full video/powerpoint presentations. Like Deloitte, the EY webcasts deal with industry specific issues related to IFRS, but EY also has sessions that focus upon specific accounts (i.e., IFRS revenue recognition, IFRS tax, IFRS hedging).

KPMG offers webcasts dealing with both IFRS industry issues and specific IFRS accounts through their KPMG IFRS Institute. In addition, they currently have five archived webcasts geared to presenting IFRS information to professors. These sessions address incorporating IFRS into classrooms and discuss various faculty surveys.

PwC hosts three separate and distinct websites of IFRS webcasts and online videos. Their newest source is perhaps the most exciting development in the whole sphere of IFRS online videos. The newly created PwC IFRS VLC is designed to assist companies in assessing the impact of transitioning to IFRS. The center is free to the public and offers a series of videos to help companies understand the differences between IFRS and U.S. GAAP. There are 6 sessions, containing a total of 16 separate 20 to 30 minute full video courses with synchronized slides.

PwC also offers three excellent short IFRS videos of approximately 7 minutes each at their PwC.tv website which has various programs and issues geared specifically to students. On channel 1 of PwC.tv the videos discuss the "What?, Why?, and How?" of IFRS. Also, PwC has developed a separate monthly IFRS Webcast series which discusses industry and specific standard issues.

In addition to the global public accounting firms' webcasts, the AICPA and the CICA have produced numerous high quality IFRS videos. The AICPA announced on May 20, 2008 the creation of their new website IFRS.com. It serves as their hub for updates, publications and videos related to IFRS. There are currently 14 short video clips ranging from 1 to 13 minutes in duration. A variety of perspectives can be observed from senators, practitioners, and institute officers. In Canada, which is adopting IFRS in 2011, the CICA has three very detailed videos ranging from 30 to 90 minutes. The videos, entitled "Get Ready", "Go Deep", and "Even Deeper" are from the June 2008 conference of the Canadian Academic Accounting Association (CAAA) which provided guidance for academics to prepare for IFRS. The Institute of Management Accountants (IMA) has also initiated an IFRS Webinar series with 5 sessions from March to September of 2009.

Finally, two excellent sources of webcasts of a more theoretical nature include the productions of the SEC and the University Forums offered each year by the Lubin School of Business at Pace University. The SEC has archived roundtables that deal with the use of IFRS by foreign registrants and also the SEC "Roadmap to IFRS". The Lubin School of Business has also archived their 2007, 2008, and 2009 forum videos dealing with IFRS issues.

For introducing IFRS within our course, we have some favorite short videos that we frequently show during the preliminary course sessions as listed in Table 4.

For the subsequent more advanced topic sessions, the entire spectrum of available IFRS webcasts and online videos may be considered for incorporation, depending upon the topics and direction the professor intends to utilize. For the two graduate and undergraduate IFRS courses that we have developed, supplementary segments of webcasts and videos are being shown. Table 5 shows how the IFRS online videos and webcasts can become an integral part of an enlivened class, either by showing video clips and webcast excerpts in class or assigning as part of required homework. 
Table 4: IFRS Introductory Online Videos for the Enlivened Stand-Alone Course: Author's Favorites

\begin{tabular}{|c|c|c|c|}
\hline Title & Source & Duration & Benefit for Students \\
\hline $\begin{array}{l}\text { IFRS: Adopting Global } \\
\text { Standards }\end{array}$ & IFRS.com & 8 minutes & $\begin{array}{l}\text { Good introduction to the topic with } \\
\text { prestigious speakers. }\end{array}$ \\
\hline PwC.tv IFRS Ready Videos & PwC.tv & $\begin{array}{l}3 \text { videos of } 7 \\
\text { minutes each }\end{array}$ & $\begin{array}{l}\text { Short videos with Partners, Professors and } \\
\text { Executives discussing IFRS. }\end{array}$ \\
\hline $\begin{array}{l}\text { Live Interview with IASB } \\
\text { Chairman, Sir David } \\
\text { Tweedie at the } 2009 \text { KPMG } \\
\text { Global Issues Forum }\end{array}$ & KPMGIFRSInstitute.com & $\begin{array}{l}\text { The first } 15 \\
\text { minutes of a one } \\
\text { hour interview }\end{array}$ & $\begin{array}{l}\text { Webcast from Hofstra University which } \\
\text { focuses on the current status of } \\
\text { International Financial Reporting } \\
\text { Standards (IFRS) and the potential for } \\
\text { adoption by the U.S. }\end{array}$ \\
\hline $\begin{array}{l}\text { Enabling IFRS Knowledge } \\
\text { Transfer }\end{array}$ & Youtube.com & 3 minutes & $\begin{array}{l}\text { Jean Wyer, Partner and Leader, PwC } \\
\text { College and University Relations points } \\
\text { out that PwC expects basic IFRS } \\
\text { knowledge when hiring graduates. }\end{array}$ \\
\hline $\begin{array}{l}\text { IFRS: SEC Chairman } \\
\text { Christopher Cox - Roadmap } \\
\text { to IFRS }\end{array}$ & IFRS.com & 11 minutes & $\begin{array}{l}\text { Former SEC Chairman Christopher Cox } \\
\text { introduces the IFRS Roadmap. }\end{array}$ \\
\hline
\end{tabular}

Table 5: Suggested Online Videos and Webcast Supplements for Selected Topics in an IFRS Course

\begin{tabular}{|c|c|c|}
\hline 1 & $\begin{array}{l}\text { Introduction, First time Adoption and Financial } \\
\text { Presentation }\end{array}$ & $\begin{array}{l}\text { PwC VLC Session 1: First-Time Adoption } \\
\text { AICPA: IFRS: Adopting Global Standards } \\
\text { PwC.tv IFRS Ready Videos: What? Why? How? }\end{array}$ \\
\hline 2 & Revenue, Inventory and Income Tax & $\begin{array}{l}\text { PwC VLC Session 1: Revenue Recognition } \\
\text { EY: Revenue Recognition Requirements (2/17/09) } \\
\text { KPMG: Tax Considerations When Converting } \\
\text { PwC: Understanding the Impact on Global Tax }\end{array}$ \\
\hline 3 & $\begin{array}{l}\text { Business Combinations, Discontinued Operations } \\
\text { and Foreign Currency }\end{array}$ & $\begin{array}{l}\text { PwC VLC Session 3: Business Combinations } \\
\text { EY: Mergers and Acquisitions Under IFRS }\end{array}$ \\
\hline 4 & Intangibles and Leases & $\begin{array}{l}\text { KPMG: R\&D and Intangible Transition (02/04/09) } \\
\text { PwC VLC Session 2: Internally Generated Intangibles } \\
\text { PwC VLC Session 3: Leases }\end{array}$ \\
\hline 5 & Impairment of Assets & $\begin{array}{l}\text { EY: Long-Lived Assets: Recognition and Impairment } \\
\text { PwC VLC Session 2: Property, Plant and Equipment } \\
\text { PwC VLC Session 2: Impairments of Nonfinancial Assets }\end{array}$ \\
\hline 6 & Provisions, Pensions and Share Based Payments & $\begin{array}{l}\text { EY: Accounting for Pensions in an IFRS World } \\
\text { EY: Share-Based Payments in and IFRS World } \\
\text { PwC VLC Session 1: Provisions \& Contingencies } \\
\text { PwC VLC Session 4: Employee Benefits }\end{array}$ \\
\hline 7 & Financial Instruments & $\begin{array}{l}\text { EY: IFRS: Fair Values and Financial Instruments (12/15/08) } \\
\text { KPMG: Financial Instruments, Fair Value }(12 / 18 / 08) \\
\text { PwC VLC Session 5: Financial Instruments }\end{array}$ \\
\hline 8 & Consolidation and Joint Ventures & $\begin{array}{l}\text { EY: Accounting for Consolidations in an IFRS World } \\
\text { PwC VLC Session 3: Consolidations }\end{array}$ \\
\hline 9 & Convergence and Standard Setting Activities & $\begin{array}{l}\text { Deloitte: GAAP \& IFRS Convergence: Bridging the Divide } \\
\text { SEC: Proposing a Roadmap Toward IFRS-Christopher Cox } \\
\text { Lubin School: Global Integration of Accounting Standards }\end{array}$ \\
\hline
\end{tabular}

The idea and techniques of utilizing "cyber-guest" lecturers as a pedagogical supplement in the teaching of IFRS has recently received very positive recognition by numerous accounting constituents. In the course evaluations submitted by our students at the end of the semester, most students cite the online videos and webcasts as a positive element to their classroom experience. The techniques used in this IFRS course were recently recognized by the AICPA and Federation of Schools of Accountancy (FSA) with Honorable Mention for the 2009 Mark Chain/ FSA Innovation in Graduate Teaching Award. The Cyber-Guest methodology was also the recipient of the best paper award for the 2009 AAA-Ohio Region for Teaching, Learning and Curriculum. Dr. Sue Haka, 
immediate past president of the AAA and Ernst \& Young Professor of Accounting at Michigan State University has written on the AAA Commons, the new collaborative, social-networking web platform for more than 8,000 AAA members:

"You have created a wonderful resource for all of us interested in bringing international issues and topics into our classes. Thanks for your contributions ... I know that I will be using some of the resources you have identified in my international accounting class in this coming Fall term."

\section{SUPPLEMENTARY RESOURCES FOR OUR IFRS COURSE}

In addition to the web-based resources of e-IFRS, e-Learning Modules and Online Videos and Webcasts, there are a variety of supplementary materials that may be integrated into an IFRS course. These consist of several IFRS textbooks that have entered the market, publications of the global accounting firms, the new IASB training modules for the IFRS SME standard and the EY IFRS curriculum.

An advantage of incorporating IFRS books into the course is that they provide additional questions and exercises for homework assignment and include power point presentations that could form the basis of class discussions.

The global accounting firms have each produced a multitude of printed publications that can be accessed and printed from their websites. Excellent comparative studies of IFRS versus U.S. GAAP have been written by the global firms that complement course sessions.

EY created a 24 module IFRS resource that provides powerpoints, problems and cases that can supplement an IFRS course. These instructor materials are available at the password protected site http://www.ey.com/us/ARC.

Another noteworthy supplement for teaching IFRS to students is the newly created Standard "IFRS for SMEs" (Small and Medium-Sized Entities) that is available through the IASB website. For the first time the IASB has created a learning program for a standard. The SME training program includes learning modules that consists of PDF Files providing commentaries and exercises for every single chapter within this standard.

Within the next 12 months the IASB will publish 15 new exposure drafts or standards, information that cannot be provided timely by using a textbook. By assigning group projects to exposure drafts and corresponding comment letters, students are given an opportunity to understand how accounting standards are created and what discussions are involved in such decisions.

\section{COMBINING THE ONLINE COURSE COMPONENTS INTO AN ENLIVENED IFRS CLASS SESSION}

The International Accounting Standard for Property, Plant and Equipment (IAS 16) provides an excellent illustration of how the aforementioned components can be combined into an enlivened class session. First, the students are assigned as homework to work through the Deloitte e-Learning Module on IAS 16 with the requirement to print out the results of their module assessment test as evidence of their work. This assignment will immerse the students into several interactive mini-cases that deal with different aspects of IAS 16 ranging from initial acquisition of Property, Plant and Equipment, to using the revaluation method of valuation subsequent to acquisition, which is unique to IFRS.

The students are advised to refer to the actual standard which they can obtain via the e-IFRS, either the unaccompanied or accompanied version. By having the actual IAS 16 either printed and on their desk or open in a separate window on their computer, the students will be able to research and find the answers to questions as they work through the various Deloitte Module scenarios. During the classroom session the class reviews the module assessment test as a group and discusses the significant topics of the module.

Also during the class session, portions of the PwC VLC session that covers IAS 16 are shown to the students so that they can hear from a PwC Partner and Senior Manager how their clients in Europe have dealt with 
the unique differences of IAS 16 such as component depreciation or revaluation of property. Students appreciate hearing from experts in the field and are also drawn to technology-based presentations, thus the short video clips capture their attention for the specific topic of the day.

In addition, supplementary powerpoints, questions and exercises from the IFRS books, IFRS SME Training Modules from the IASB or EY IFRS Curriculum can be considered for classroom presentation or additional homework assignments.

\section{STUDENTS LEARN AICPA CORE COMPETENCIES}

The course we have designed not only provides the student with practical IFRS skills and knowledge; it also addresses numerous core competencies that have been laid out by the AICPA. According to www.aicpa.org/edu/corecomp.htm the AICPA defines core competencies as:

"A set of requisite competencies for all students preparing to enter the newly envisioned accounting profession that is positioned higher on the information value chain. Competencies are categorized as functional (technical competencies most closely aligned with the value contributed by accounting professionals), personal (individual attributes and values) and broad business perspective competencies (relating to understanding of internal and external business contexts)."

Table 6 describes the specific AICPA core competencies addressed and examples of activities built into our course to support student development.

Table 6: Core Competencies of the AICPA Addressed by the Enlivened IFRS Course

\begin{tabular}{|c|l|}
\hline AICPA Core Competencies & IFRS Course Activities Supporting Competencies \\
\hline Functional Competencies & $\begin{array}{l}\text { Students acquire knowledge of the relevant IFRS standards related to } \\
\text { measurement and reporting as well as the IASB Conceptual } \\
\text { Framework }\end{array}$ \\
\hline $\begin{array}{l}\text { Leverage Technology to Develop and Enhance } \\
\text { Functional Competencies }\end{array}$ & $\begin{array}{l}\text { Students gain valuable experience in accessing and using the e-IFRS } \\
\text { database created by the IASB and also access and learn how to use a } \\
\text { highly sophisticated online interactive training program created by a } \\
\text { global accounting firm. }\end{array}$ \\
\hline Personal Competencies & $\begin{array}{l}\text { Students solve questions, exercises, problems and cases involving } \\
\text { numerous IFRS standards for reporting, measurement and statement } \\
\text { presentation }\end{array}$ \\
\hline Problem Solving and Decision Making & $\begin{array}{l}\text { Students become proficient in working in realistic case studies via the } \\
\text { Deloitte e-Learning Modules and researching the e-IFRS to help solve } \\
\text { related exercises. }\end{array}$ \\
\hline $\begin{array}{l}\text { Leverage Technology to Develop and Enhance } \\
\text { Personal Competencies }\end{array}$ & $\begin{array}{l}\text { Global and international issues are integrated throughout the IFRS } \\
\text { course material, assignments and discussions. }\end{array}$ \\
\hline Broad Business Perspective Competencies & \multicolumn{2}{|c|}{ International/ Global Perspective }
\end{tabular}

\section{CONCLUSION: BENEFITS FOR PROFESSORS AND STUDENTS}

There are very valuable and engaging pedagogical web-based resources available to teach and learn IFRS. By combining the online electronic version of the actual IFRS standards with the e-Learning Modules from Deloitte, along with selected expert video clips and webcast excerpts, a very practical and enlivened IFRS course can be developed and offered. An additional benefit of the course elements is the low cost involved of accessing the components. In fact, if a textbook is not added to the mix of materials utilized by the professor, the materials cost to the students for a highly sophisticated multi-million dollar IFRS learning experience would be zero. In addition, students have access to the latest information, online interviews and standards - a superior trait of our course. 
Students of this course develop skills in researching and applying IFRS standards that will benefit them in their future careers. The student exposure to a variety of IFRS experts via the videos and webcasts emphasizes the importance of learning IFRS now and opens their eyes to how leading professionals view the IFRS revolution that is occurring.

The sources and techniques used within our IFRS course may also be applied to many other courses in the accounting curriculum from intermediate levels to theory level courses. The IFRS curriculum presented provides a valuable alternative to the typical book-based accounting course and may even stimulate thought of how to make other courses in the accounting curriculum more engaging.

\section{AUTHOR INFORMATION}

Mark Holtzblatt, Ph.D., CPA, is the Frederick Addy Professor of Accounting and Finance at Roosevelt University in Chicago. He was awarded a 2008 PricewaterhouseCoopers IFRS Ready Grant to develop a new class dealing with International Financial Reporting Standards (IFRS) and an honorable mention for the 2009 Mark Chain/Federation of Schools of Accountancy award for Innovation in Graduate Teaching Award. Mark has published articles and made numerous AAA and Academy of International Business (AIB) conference presentations regarding IFRS.

Norbert Tschakert, Ph.D., CPA, CFE, is an Assistant Professor of Accounting at the University of the Virgin Islands in the United States Virgin Islands. Norbert holds multiple Certifications in International Accounting and consults for the AICPA regarding their forthcoming IFRS Certificate. He received the 2010 IBFR Best Research Award. His research interests are International Accounting, Pedagogy of International Accounting, International Auditing and Forensic Accounting.

\section{REFERENCES}

1. American Institute of Certified Public Accountants (AICPA) (2010). “AICPA IFRS Resources.” [Web page]. Retrieved from http://www.ifrs.com

2. American Institute of Certified Public Accountants (AICPA) (2010). "Core Competency Framework \& Educational Competency Assessment Web Site." [Web page]. Retrieved from http://ceae.aicpa.org/Resources/Education+and+Curriculum+ Development/Core+Competency+Framework+and+Educational+Competency+Assessment+Web+Site

3. American Institute of Certified Public Accountants (AICPA) (2008). "IFRS: Adopting Global Standards." [Web video]. Retrieved from http://www.ifrs.com/video.html?bcpid=1529569170\&bclid=1493222124\&bctid=1553183653

4. American Institute of Certified Public Accountants (AICPA) (2010). "Mark Chain/FSA Innovation in Graduate Teaching Award." [Web page]. Retrieved from http://ceae.aicpa.org/Resources/ Scholarships+and+Awards

5. $\quad$ American Accounting Association (AAA) (2010). "AAA Commons." Retrieved from http://commons.aaahq.org/pages/home

6. $\quad$ American Accounting Association (AAA) (2009). “AAA 2009 Ohio Region Meeting.” [Web page]. Retrieved from http://aaahq.org/ohio/2009/program.htm

7. Association of Chartered Certified Accountants (ACCA) (2010). "Certificate in International Financial Reporting." [Web page]. Retrieved from http://www.accaglobal.com/members/qualifications/cifr

8. Canadian Institute of Chartered Accountants (CICA) (2008). "2008 CAAA Conference Presentations." [Web page]. Retrieved from http://www.cica.ca/ifrs/academic-resources/index.aspx

9. Deloitte (2010). "Dbriefs: Webcast Series for Executives." [Web page]. Retrieved from http://www.usdbriefs.com/files/guide.pdf

10. Deloitte (2010). "IAS Plus Homepage.” [Web page]. Retrieved from http://www.iasplus.com/index.htm

11. Deloitte (2010). "IFRS e-Learning." [Web page]. Retrieved from http://www.deloitteifrslearning.com

12. Ernst \& Young (2009). "Ernst \& Young expands its commitment to help universities prepare students for IFRS.” Retrieved from http://www.ey.com/US/en/Newsroom/News-releases/Ernst-and-Young-expands-itscommitment-to-help-universities-prepare-students-for-IFRS 
13. Ernst \& Young (2010). “Thoughtcenter Webcasts and Podcasts.” [Web page]. Retrieved from http://webcast.ey.com/thoughtcenter

14. Institute of Chartered Accountants in England and Wales (ICAEW) (2010). "IFRS Learning and Assessment Program." [Web page]. Retrieved from http://www.icaew.com/index.cfm/route/134994/icaew_ga/en/ Qualifications/IFRS/Programme_overview/Programme_overview

15. International Association for Accounting Education and Research (IAAER) (2010). "International Association for Accounting Education and Research.” [Web page]. Retrieved from http://www.iaaer.org

16. International Accounting Standards Board (IASB) (2010). "Access the Unaccompanied IFRSs." [Web page]. Retrieved from http://www.iasb.org/IFRSs/IFRS.htm

17. International Accounting Standards Board (IASB) (2010). "IFRS for SMEs.” [Web page] Retrieved from http://www.iasb.org/IFRS+for+SMEs/IFRS+for+SMEs.htm

18. KPMG (2010). "KPMG IFRS Institute.” [Web page]. Retrieved from http://www.kpmginstitutes.com/topics/ifrs.aspx

19. Pace University Lubin School of Business (2010). "Lubin Forum on Contemporary Accounting Issues." [Web page]. Retrieved from http://www.pace.edu/pace/lubin/news-events/lubin-forum-on-contemporaryaccounting-issues

20. PricewaterhouseCoopers (2009). "Enabling IFRS Knowledge Transfer.” [Web video]. Retrieved from http://www.youtube.com/watch?v=iQ-zqfOUpzM

21. PricewaterhouseCoopers (2008). "IFRS Ready: Why? What? How?" [Web videos]. Retrieved from http://www.pwc.com/us/en/careers/pwctv/channel-1-ifrs.jhtml

22. PricewaterhouseCoopers (2010). "IFRS Video Learning Center." [Web page]. Retrieved from http://www.pwc.com/us/en/issues/ifrs-reporting/ifrs-video-learning-center.jhtml

23. PricewaterhouseCoopers (2010). "PwC IFRS Ready Grant Program.” [Web page]. Retrieved from http://www.pwc.com/us/en/faculty-resource/ifrs-ready_rfp.jhtml

24. PricewaterhouseCoopers (2010). "P2P IFRS e-Learning." [Web page]. Retrieved from http://www.pwc.com/th/en/assurance/p2p-ifrs-e-learning.jhtml

25. Securities and Exchange Commission (SEC) (2008). "Roadmap for the Potential use of Financial Statements Prepared in Accordance with International Financial Reporting Standards by U.S. Issuers." [Web page]. Retrieved from http://www.sec.gov/rules/proposed/2008/33-8982.pdf 
NOTES 